Terbit online pada laman web jurnal : http://jurnal.iaii.or.id

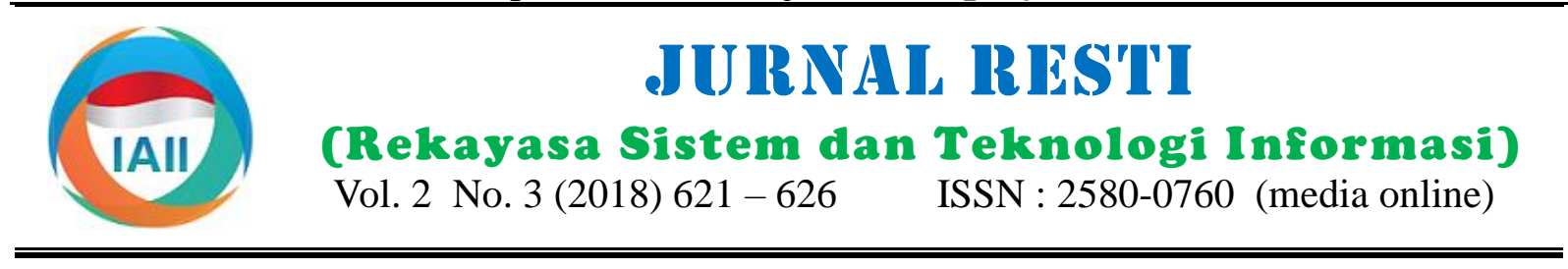

\title{
Perbandingan Algoritma K-Means Dengan Algoritma Fuzzy C-Means Untuk Clustering Tingkat Kedisiplinan Kinerja Karyawan
}

\author{
Nova Agustina ${ }^{\mathrm{a}}$, Prihandoko ${ }^{\mathrm{a}}$ \\ ${ }^{a}$ Program Studi Teknik Informatika - Sekolah Tinggi Teknologi Bandung, nova@sttbandung.ac.id \\ ${ }^{\mathrm{b}}$ Fakultas Ilmu Komputer dan Teknologi Informasi-Universitas Gunadarma Jakarta, pri@staff.gunadarma.ac.id
}

\begin{abstract}
STT Bandung is university that has great potential to become a leading university of Bandung. To achieve the purpose of college, one of the stages that must be done is the evaluation of employee performance, namely by monitoring employee discipline. To facilitate the determination of the level of employee discipline is required data mining techniques to cluster of data. In data mining there are several methods of data clusters, which is often used is the method of K-Means with Fuzzy CMeans. Based on the research conducted both methods are grouping employee performance data into 3 clusters, namely high performance level, the level of medium performance level and low performance level. The results of this study indicate that the Fuzzy C-Means method is a better method than K-Means to do data clustering on the level of employee performance in STT Bandung because the value of validation is close to 1.
\end{abstract}

Keywords: Data Mining, Comparison, K-Means, Fuzzy C-Means

\begin{abstract}
Abstrak
STT Bandung merupakan perguruan tinggi swasta yang memiliki potensi besar untuk menjadi perguruan tinggi terkemuka di Kota Bandung. Untuk mencapai tujuan perguruan tinggi, salah satu tahap yang harus dilakukan adalah evaluasi kinerja karyawan, yakni dengan pemantauan kedisiplinan karyawan. Untuk memudahkan penentuan tingkat kedisiplinan karyawan maka diperlukan teknik data mining untuk mengklaster data. Pada data mining terdapat beberapa metode klaster data, yang sering digunakan adalah metode K-Means dengan Fuzzy C-Means. Berdasarkan penelitian yang dilakukan kedua metode tersebut mengelompokan data kinerja karyawan menjadi 3 kluster, yakni tingkat kinerja tinggi, tingkat kinerja sedang dan tingkat kinerja rendah. Hasil dari penelitian ini menunjukkan bahwa metode Fuzzy C-Means adalah metode yang lebih baik dibandingkan K-Means untuk melakukan mengklasteran data pada tingkat kinerja karyawan di STT Bandung karena nilai validasinya bernilai mendekati 1 .
\end{abstract}

Kata kunci : Data Mining, Perbandingan, K-Means, Fuzzy C-Means

(C) 2018 Jurnal RESTI

\section{Pendahuluan}

STT-Bandung (Sekolah Tinggi Teknologi Bandung) merupakan salah satu perguruan tinggi swasta di Kota Bandung yang sedang berkembang dan memiliki potensi besar untuk menjadi perguruan tinggi terkemuka di Kota Bandung. . Untuk mencapai tujuan menjadi perguruan tinggi yang terkemuka, tentu STTBandung perlu menyeimbangkan kebutuhan dengan kemajuan teknologi.

Penilaian karyawan merupakan salah satu tahap evaluasi kerja yang dapat meningkatkan kualitas sumber daya manusia. Penilaian kedisiplinan kinerja karyawan adalah salah satu faktor untuk memperbaiki situasi kualitas sumber daya manusia. Pemantauan dan penilaian kedisiplinan karyawan harus dilakukan secara terus menerus menjadi sebagian ciri manajemen telah berjalan dengan baik sebagai tolak ukur pertimbangan sasaran yang telah ditetapkan.

Untuk memudahkan pihak manajemen menentukan tinngkat kedisiplinan kinerja karyawan, maka teknik clustering data perlu digunakan. Pengelompokan data atau clustering merupakan suatu metode yang digunakan dalam data mining yang cara kerjanya mencari dan mengelompokkan data yang mempunyai kemiripan karakteristik antara data satu dengan data lainnya yang diperoleh [7] Dari beberapa teknik clustering data yang paling sederhana dan umum menggunakan Algoritma K-Means dan Fuzzy C-Means sebagai pembanding dimana hasil dari kedua algoritma tersebut dibandingkan 
Penelitian ini bertujuan untuk membandingkan 2.3 Algoritma Fyzzy C-Means algoritma k-means dengan fuzzy c-means untuk melihat kemampuan dari setiap algoritma dalam clustering sehingga mendapatkan hasil yang terbaik di Sekolah Tinggi Teknologi Bandung menggunakan data presensi karyawan pada tahun 2017. Manfaat penelitian ini agar menjadi referensi selanjutnya dalam meggunakan metode clustering.

\section{Tinjauan Pustaka}

\subsection{Data Mining}

Data mining adalah proses menemukan pola yang menarik dan pengetahuan dari sejumlah besar data. Sumber data dapat mencakup database, gudang data, Tahapan clustering menggunakan algoritma fuzzy cweb, repositori informasi lainnya, atau data yang means:

dialirkan ke dalam sistem dinamis [8]. Data mining a. Masukkan data yang akan diklaster, berupa matriks biasa digunakan untuk klasifikasi, clustering, prediksi, estimasi, asosiasi maupun deskripsi data.

\subsection{Algoritma K-Means}

Algoritma K-Means adalah bekerja dengan membagi data ke dalam $\mathrm{k}$ buah cluster yang telah ditentukan [9] Algoritma K-Means merupakan algoritma yang sering digunakan karena penggunaannya yang sederhana dan mudah untuk diimplementasikan. Algoritma K-means merupakan metode berbasis jarak yang membagi data dalam sejumlah cluster dan setiap tahapan tertentu terhadap suatu objek. Algoritma K-Means memiliki aturan yaitu ada jumlah cluster yang akan diinputkan dan hanya memiliki atribut bertipe numerik.

Tahapan clustering menggunakan algoritma k-means:

a. Memasukan data

b. Menentukan jumlah klaster

c. Ambil sebarang data sebanyak jumlah klaster secara acak sebagai pusat klaster (sentroid).

d. Hitung jarak antara data dengan pusat klaster, dengan menggunakan persamaan :

$$
D(i, j)=\sqrt{\left(x_{1 i}-x_{1 j}\right)^{2}+. .+\left(x_{k i}-x_{k j}\right)^{2}}
$$

Dimana:

$(i, j)=$ jarak data $i$ ke pusat kluster $j$,

$x k i=$ data ke $i$ pada atribut ke $j$,

$x j i=$ titik pusat ke $j$, pada atribut $k$ e.

e. Hitung kembali pusat klaster dengan keanggotaan klaster yang baru

f. Jika pusat klaster tidak berubah maka proses klaster telah selesai, jika belum maka ulangi langkah ke d sampai pusat klaster tidak berubah lagi.

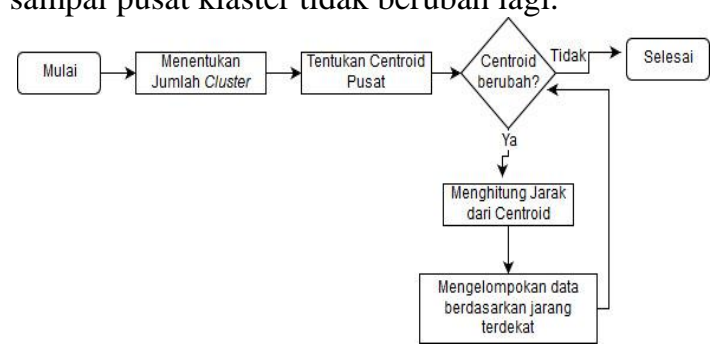

berukuran $n \times \mathrm{m}$

b. Tentukan:
i. Jumlah cluster (c)
ii. Pangkat (w)
iii. Maksimum Iterasi (Max Iter)
iv. Error terkecil $(\varepsilon)$
v. Fungsi objektif awal $=P 0=0$
vi. Iterasi awal $=\mathrm{t}=1$

c. Bangkitkan bilangan acak ( $\mu i k)$, dengan $i=1,2, \ldots, n$; $k=1,2, \ldots, n$; dan $c$ sebagai elemenelemen matriks partisi awal U.

Hitung jumlah setiap kolom :

$$
\begin{aligned}
Q_{i=} & \sum_{k=1 \mu i k}^{c} \\
& \text { Dengan } \mathrm{j}=1,2, \ldots, \mathrm{n}
\end{aligned}
$$

Hitung:

$$
\mu_{i k}=\frac{\mu_{i k}}{Q_{i}}
$$

d. Hitung pusat klaster ke- $\mathrm{k}:$ Vkj

$$
V_{k j}=\frac{\sum_{i=1(\mu i k)}^{n}{ }^{w} \times x_{i j}}{\sum_{i=1(\mu i k)^{w}}^{n}}
$$

e. Hitung fungsi objektif pada iterasi ke- $\mathrm{t}$

$$
P_{t}=\sum_{t=1}^{n} \sum_{k=1}^{c}\left(\left[\sum_{j=1}^{m}\left(X_{i j}-V_{k j}\right)^{2}\right]\left(\mu_{i k}\right)^{w}\right)
$$

f. Hitung perubahan matriks partisi

$$
\mu_{i k}=\frac{\left[\sum_{j=1}^{m}\left(X_{i j}-V_{k j}\right)^{2}\right]^{\frac{-1}{w-1}}}{\sum_{k=1}^{c}\left[\sum_{j=1}^{m}\left(X_{i j}-V_{k j}\right)^{2}\right]^{\frac{-1}{w-1}}}
$$

g. Cek kondisi berhenti: a. Jika: $(|P t-P t-1|$ MaxIter $)$ maka berhenti, b.Jika tidak: $t=t+1$, ulangi langkah ke-4 Output yang dihasilkan dari Fuzzy C-Means (FCM) merupakan deretan pusat klaster dan beberapa derajat keanggotaan untuk tiap-tiap titik data.

Gambar 1. Flowchart K-Means

Jurnal RESTI (Rekayasa Sistem dan Teknologi Informasi) Vol . 2 No. 3 (2018) 621- 626 


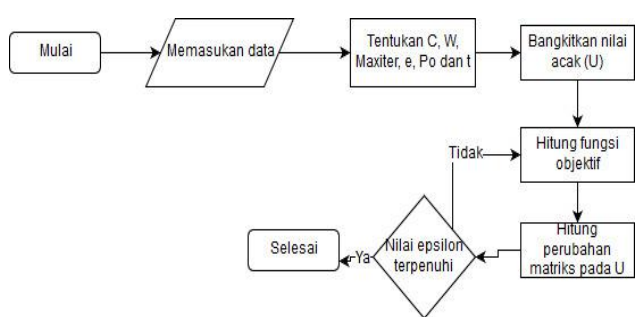

Gambar 2. Flowchart Fuzzy C-Means

\section{Metodologi Penelitian}

\subsection{Jenis, Sifat dan Pendekatan Penelitian}

Metode analisis data yang dipakai adalah Penelitian Tindakan. Tahap awal adalah melakukan pengumpulan data melalui observasi, wawancara dan studi literatur. Selanjutnya adalah membandingkan Algoritma KMeans dengan Fuzzy C-Means, kemudian membuat rancangan sistem dan pengujian diakhiri dengan implementasi.

\subsection{Metode Analisis Data}

Metode analisis data yang dipakai adalah Metode Perbandingan Eksponensial. Tingkat kedisiplinan diukur melalui perbandingan hasil nilai penilaian tingkat kinerja menggunakan Algoritma K-Means dengan Algoritma Fuzzy C-Means. Pengukuran dipilih berdasarkan hasil dari teknik implementasi algoritma yang paling sesuai atau mendekati. Data yang berkaitan dengan presensi karyawan di STT Bandung terlebih dahulu diambil kemudian dilakukan clustering. Hasil cluster merupakan pengelompokan tingkat kinerja karyawan, terdiri dari Tingkat Kinerja Tinggi, Tingkat Kinerja Sedang dan Tingkat Kinerja Rendah.

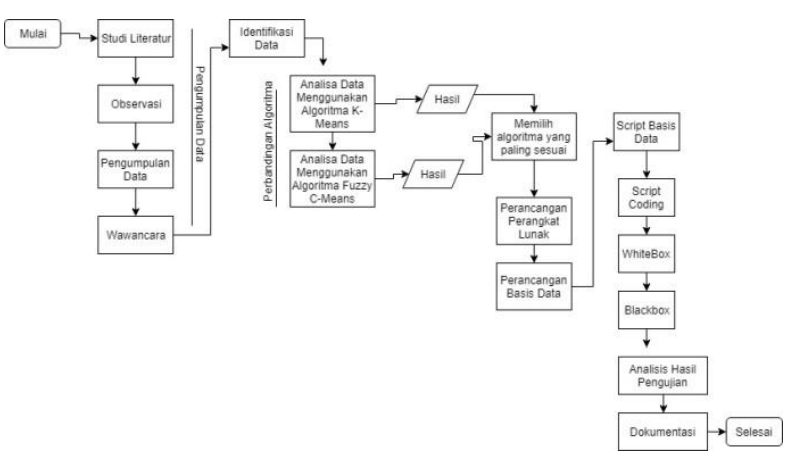

Gambar 3. Alur Penelitian

\section{Hasil dan Pembahasan}

Pada penelitian ini akan menjelaskan mengenai perbandingan clustering data kinerja karyawan di STT Bandung menggunakan metode K-Means dan Fuzzy CMeans. Untuk menentukan pusat centroid setiap cluster memiliki cara yang berbeda pada metode Algoritma KMeans dengan Fuzzy C-Means. Data yang dianalisa adalah data jumlah masuk, jumlah ijin dan jumlah terlambat karyawan di STT-Bandung pada tahun 2017. Jumlah cluster yang akan dibentuk terdiri dari 3 klaster, dimana klaster 1 dikategorikan tingkat kedisiplinan kinerja tinggi, klaster 2 dikategorikan tingkat kedisiplinan tingkat sedang, dan klaster 3 dikategorikan tingkat kedisiplinan kinerja rendah. Tabel data presensi karyawan adalah sebagai berikut:

Tabel 1.Data Presensi Karyawan

\begin{tabular}{lllll}
\hline No & NIK & Masuk & Ijin & Terlambat \\
\hline 1 & 06.77 .003 & 259 & 54 & 59 \\
2 & 08.82 .004 & 257 & 56 & 12 \\
3 & 09.81 .007 & 281 & 32 & 55 \\
4 & 17.94 .049 & 112 & 201 & 18 \\
5 & 91.63 .001 & 235 & 78 & 107 \\
$\ldots$. & $\ldots \ldots$ & $\ldots \ldots$ & $\ldots$. & $\ldots$ \\
34 & 97.73 .002 & 265 & 28 & 75 \\
\hline
\end{tabular}

Pada tabel 1 dapat dilihat jumlah masuk, ijin dan terlambat karyawan di Sekolah Tinggi Teknologi Bandung selama satu tahun pada tahun 2017.

\subsection{Metode Algoritma K-Means}

Tahap pertama untuk clustering pada algoritma KMeans adalah menentukan pusat centroid setiap klaster. Pusat centroid ditentukan secara random pada iterasi 1 berdasarkan data yang sudah ada. Pada tahap ini ditentukan pusat centroid secara random sebagai berikut :

Tabel 2.Pusat Centroid Klaster

\begin{tabular}{llll}
\hline & Masuk & Ijin & Terlambat \\
\hline C1 & 296 & 17 & 52 \\
C2 & 240 & 71 & 12 \\
C3 & 205 & 108 & 65 \\
\hline
\end{tabular}

Selanjutnya adalah menghitung jarak terhadap pusat klaster menggunakan rumus :

$$
D(i, j)=\sqrt{\left(x_{1 i}-x_{1 j}\right)^{2}+. .+\left(x_{k i}-x_{k j}\right)^{2}}
$$

Contoh menghitung jarak terhadap pusat untuk nik 06.77.003:

Klaster $1(\mathrm{C} 1)$

$$
\begin{aligned}
D(06.77 \cdot x, C 1) & =\sqrt{(259-246)^{2}+(54-17)^{2}+(69-52)^{2}} \\
& =55.018
\end{aligned}
$$

Klaster $2(\mathrm{C} 2)$

$$
\begin{aligned}
D(06.77 \cdot x, C 1) & =\sqrt{(259-240)^{2}+(54-71)^{2}+(69-12)^{2}} \\
& =40.012
\end{aligned}
$$

Klaster 3(C3)

$D(06.77 . x, C 1)=\sqrt{(259-205)^{2}+(54-108)^{2}+(69-65)^{2}}$ $=256.166$

Sehingga didapatkan hasil jarak berikut ini untuk Iterasi 1:

Tabel 3. Jarak Terhadap Centroid Pusat

\begin{tabular}{lllll}
\hline No & NIK & C1 & C2 & C3 \\
\hline 1 & 06.77 .003 & 55.018 & 40.012 & 286.166 \\
2 & 08.82 .004 & 68.132 & 31.112 & 282.449 \\
3 & 09.81 .007 & 21.424 & 57 & 315.941 \\
4 & 17.94 .049 & 262.427 & 186.134 & 78.460 \\
5 & 91.63 .001 & 102.308 & 71.895 & 260.190 \\
$\ldots$. & $\ldots \ldots$. & $\ldots \ldots$ & $\ldots$. & $\ldots$ \\
34 & 97.73 .002 & 49.507 & 49.889 & 295.328 \\
\hline
\end{tabular}

Selanjutnya adalah menentukan keanggotaan klaster dan jarak minimum. 
Nova Agustina, Prihandoko Jurnal RESTI (Rekayasa Sistem dan Teknologi Informasi) Vol . 2 No. 3 (2018) 621 - 626

Tabel 4.Keanggotaan Klaster

\begin{tabular}{lllll}
\hline No & NIK & MJ & Ka & KMJ \\
\hline 1 & 06.77 .003 & 40.012 & C2 & 286.166 \\
2 & 08.82 .004 & 31.112 & C2 & 282.449 \\
3 & 09.81 .007 & 21.424 & C1 & 315.941 \\
4 & 17.94 .049 & 78.460 & C3 & 78.460 \\
5 & 91.63 .001 & 71.893 & C2 & 260.190 \\
$\ldots$. & $\ldots \ldots$ & $\ldots \ldots$ & $\ldots$. & $\ldots$ \\
34 & 97.73 .002 & 49.507 & $\mathrm{C} 1$ & 295.328 \\
\hline
\end{tabular}

Dimana :

$\mathrm{Ka}=$ Keanggotaan

$\mathrm{MJ}=$ Minimal Jarak

KMJ = Kuadrat Min Jarak

Selanjutnya adalah menentukan pusat klaster baru:

\begin{tabular}{|c|c|c|c|c|}
\hline No & NIK & $\mathrm{C} 1$ & $\mathrm{C} 2$ & C3 \\
\hline & & $\mathrm{M}, \mathrm{I}, \mathrm{T}$ & $\mathrm{M}, \mathrm{I}, \mathrm{T}$ & $\mathrm{M}, \mathrm{I}, \mathrm{T}$ \\
\hline 1 & 06.77 .003 & & $259,54,59$ & \\
\hline 2 & 08.82 .004 & & $257,56,12$ & \\
\hline 3 & 09.81 .007 & $281,32,55$ & & \\
\hline 4 & 17.94.049 & & & $112,201,18$ \\
\hline 5 & 91.63 .001 & & $235,78,2017$ & \\
\hline$\ldots$ & $\ldots \ldots$ & $\ldots \ldots$ & $\ldots$ & $\ldots$ \\
\hline 34 & 97.73 .002 & $265,48,75$ & & \\
\hline
\end{tabular}

Dimana:

M,I,T = Masuk, Ijin, Terlambat

Pusat klaster baru ditentukan dengan menjumlahkan seluruh jumlah masuk $\mathrm{C} 1$, jumlah Ijin $\mathrm{C} 1$, Terlambat C1 kemudian dibagi dengan jumlah keanggotaan. Begitupun dengan Klaster 2 dan Klaster 3. yang ada pada pusat klaster baru, contoh:

$$
\begin{array}{ll}
\text { M1 } & =(281+. .+265) / 12=278.833 \\
\text { I1 } & =(32+. .+48) 12=34.166 \\
\text { T2 } & =(55+. .+75) / 12=65.75
\end{array}
$$

Didapatkan hasil sebagai berikut:

Tabel 5.Pusat Centroid Klaster

\begin{tabular}{llll}
\hline & Masuk & Ijin & Terlambat \\
\hline C1 & 278.833 & 34.166 & 65.75 \\
C2 & 238.894 & 74 & 59.631 \\
C3 & 93.666 & 219.333 & 27.333 \\
\hline
\end{tabular}

Kemudian lanjutkan ke Iterasi selanjutnya menggunakan Pusat Centroid Klaster Baru hingga keanggotan baru dengan keanggotaan sebelumnya tidak berubah.

Berdasarkan data yang telah diperoleh dan diolah menggunakan algoritma K-means didpatkan hasil clustering pada tabel 6 .

Tabel 6. Tabel Hasil Clustering Menggunakan Algoritma KMeans

\begin{tabular}{llllll}
\hline No & NIK & C1 & C2 & C3 & Hasil \\
\hline 1 & 06.77 .003 & 20,378 & 47,022 & 23,750 & C1 \\
2 & 08.82 .004 & 53,766 & 67,443 & 23,149 & C1 \\
3 & 09.81 .007 & 13,762 & 78,218 & 26,637 & C1 \\
4 & 17.94 .049 & 230,80 & 167,45 & 27,556 & C3 \\
5 & 91.63 .001 & 69,868 & 45,463 & 215,16 & C2 \\
$\ldots$. & $\ldots \ldots$ & $\ldots \ldots$ & $\ldots$. & $\ldots$ & $\ldots$ \\
34 & 97.73 .002 & 17,239 & 49.889 & 246,94 & C1 \\
\hline
\end{tabular}

Klaster 1 .2 dan 3 dibandingkan kemudian ambil klaster dengan nilai terkecil untuk menentukan keanggotaan klaster.

\subsection{Metode Algoritma Fuzzy C-Means}

Tahap pertama untuk clustering pada algoritma Fuzzy C-Means adalah menentukan jumlah cluster yang dicari, maksimum iterasi, nilai pembobot dan nilai kesalahan terkecil sesuai dengan kebutuhan, dimana pada studi ini peneliti menentukan nilai-nilai tersebut dapat dilihat pada tabel 7 .

Tabel 7. Penentuan nilai awal Fuzzy C-Means

\begin{tabular}{lll}
\hline No & Kebutuhan & Jumlah \\
\hline 1 & Jumlah Cluster yang Dicari & 3 \\
2 & Maksimum Iterasi & 100 \\
3 & Nilai Pembobot (Pangkat) & 2 \\
4 & Nilai Kesalahan Terkecil & 0.000001 \\
\hline
\end{tabular}

Selanjutnya adalah menentukan matriks keanggotaan secara random, kenanggotaan yang dilakukan oleh peneliti pada studi ini adalahs ebagai berikut:

Tabel 8. Matriks Keanggotaan

\begin{tabular}{lllll}
\hline NIK & C1 & C2 & C3 & Jumlah \\
\hline 06.77 .003 & 0.3 & 0.3 & 0.4 & 1 \\
08.82 .004 & 03 & 0.5 & 0.2 & 1 \\
09.81 .007 & 0.8 & 0.1 & 0.1 & 1 \\
17.94 .049 & 0.5 & 0.2 & 0.3 & 1 \\
91.63 .001 & 0.3 & 0.3 & 0.4 & 1 \\
$\ldots \ldots$ & $\ldots \ldots$. & $\ldots \ldots$ & $\ldots \ldots$ & $\ldots$ \\
97.73 .002 & 0.3 & 0.5 & 0.2 & 1 \\
\hline
\end{tabular}

Dimana :

$\mathrm{C} 1+\mathrm{C} 2+\mathrm{C} 3=1$.

Setelah menentukan matriks secara random, selanjutnya adalah menentukan miu $^{2}$ berdasarkan matriks random yang telah ditentukan, dapat dilihat pada tabel 9.

Tabel 9. $\mathrm{Miu}^{2}$

\begin{tabular}{llll}
\hline NIK & C1 & C2 & C3 \\
\hline 06.77 .003 & 0.09 & 0.09 & 0.016 \\
08.82 .004 & 0.09 & 0.025 & 0.04 \\
09.81 .007 & 0.064 & 0.01 & 0.01 \\
17.94 .049 & 0.025 & 0.04 & 0.09 \\
91.63 .001 & 0.09 & 0.09 & 0.016 \\
$\ldots \ldots$ & $\ldots \ldots$. & $\ldots \ldots$ & $\ldots$. \\
97.73 .002 & 0.09 & 0.025 & 0.04 \\
TOTAL & 6.41 & 3.57 & 4.48 \\
\hline
\end{tabular}

Setelah mendapatkan hasil dari $\mathrm{Miu}^{2}$, selanjutnya adalah mengalikan cluster pada masing-masing miu dengan data presensi karyawan (masuk, ijin, terlambat) sehingga didapatkan hasil yang dapat dilihat pada tabel 10,11 dan 12 .

\begin{tabular}{llll}
\multicolumn{4}{c}{ Tabel 10. $\mathrm{Miu}^{2} \mathrm{X} 1$} \\
\hline NIK & $\mathrm{C} 1$ & $\mathrm{C} 2$ & $\mathrm{C} 3$ \\
\hline 06.77 .003 & 23.31 & 4.86 & 6.21 \\
08.82 .004 & 23.13 & 5.04 & 1.08 \\
09.81 .007 & 179.84 & 20.48 & 35.2 \\
17.94 .049 & 65 & 13.25 & 25.75 \\
91.63 .001 & 21.15 & 7.02 & 9.63 \\
$\ldots \ldots$ & $\ldots \ldots$. & $\ldots \ldots$ & $\ldots$. \\
97.73.002 & 23.85 & 4.32 & 6.75 \\
TOTAL & 1546,65 & 458,4 & 366,13 \\
\hline
\end{tabular}


Tabel 11. $\mathrm{Miu}^{2} \mathrm{X} 2$

\begin{tabular}{llll}
\hline NIK & C1 & C2 & C3 \\
\hline 06.77 .003 & 23.31 & 4.86 & 6.21 \\
08.82 .004 & 64.25 & 14 & 3 \\
09.81 .007 & 2.81 & 0.32 & 0.55 \\
17.94 .049 & 10.4 & 2.12 & 4.12 \\
91.63 .001 & 21.15 & 7.02 & 9.63 \\
$\ldots \ldots$ & $\ldots \ldots$. & $\ldots \ldots$ & $\ldots \ldots$ \\
97.73 .002 & 66.25 & 12 & 18.75 \\
TOTAL & 827,15 & 290,24 & 222,91 \\
\hline
\end{tabular}

Tabel 12. $\mathrm{Miu}^{2} \mathrm{X} 3$

\begin{tabular}{llll}
\hline NIK & C1 & C2 & C3 \\
\hline 06.77 .003 & 41.44 & 8.64 & 11.04 \\
08.82 .004 & 10.28 & 2.24 & 0.48 \\
09.81 .007 & 2.81 & 0.32 & 0.55 \\
17.94 .049 & 23.4 & 4.77 & 9.27 \\
91.63 .001 & 37.6 & 12.48 & 17.12 \\
$\ldots \ldots$ & $\ldots \ldots$. & $\ldots \ldots$ & $\ldots$. \\
97.73 .002 & 10.6 & 1.92 & 3 \\
TOTAL & 1109,78 & 292,44 & 257,68
\end{tabular}

Pusat klaster baru ditentukan dengan menjumlahkan seluruh jumlah masuk $\mathrm{C} 1$, jumlah Ijin $\mathrm{C} 1$, Terlambat $\mathrm{C} 1$ pada $\mathrm{Miu}^{2}$ kemudian dibagi dengan jumlah keanggotaan $\mathrm{Miu}^{2} \mathrm{X} 1, \mathrm{X} 2$ dan X3.Contoh perhitungan dan hasil dapat dilihat berikut:

$$
V_{k j}=\frac{\left.\sum_{i=1(\mu i k)}^{n}\right)^{w} \times x_{i j}}{\sum_{i=1(\mu i k)^{n}}^{n}}
$$

$$
\begin{aligned}
& \mathrm{M} 1=1546.65 / 6.41=241.28 \\
& \mathrm{I} 1:=458.4 / 3.57=71.51 \\
& \mathrm{~T} 1=366.13 / 4.48=57.11
\end{aligned}
$$

Tabel 13. Pusat Cluster

\begin{tabular}{llll}
\hline & Masuk & Ijin & Terlambat \\
\hline C1 & 241.28 & 71.51 & 57.11 \\
C2 & 231.69 & 81.29 & 62.43 \\
C3 & 247.71 & 65.27 & 57.51 \\
\hline
\end{tabular}

Langkah selanjutnya adalah menghitung jumlah setiap kolom, contoh:

$$
Q_{i=} \sum_{k=1 \mu i k}^{c}
$$

$\mathrm{M} 1=\left((259-241.28)^{2}+(54-241.28)^{2}+(59-241.28)^{2)}=761.63\right.$ $\mathrm{I} 1=\left((259-71.51)^{2}+(54-71.51)^{2}+(59-71.51)^{2}\right.$

$=1533.89$

$\mathrm{T} 1=\left((259-57.51)^{2}+(54-57.51)^{2}+(59-57.51)^{2}\right.$

$=386.27$

Selanjutnya adalah menghitung nilai $\mathrm{L}$, dimana $\mathrm{L}=$ X_V dikalikan dengan $\mathrm{Miu}^{2}$. Hasilnya dapat dilihat pada tabel 14 .

Tabel 14. Nilai L

\begin{tabular}{lllll}
\hline NIK & C1 & C2 & C3 & Total \\
\hline 06.77 .003 & 68.54 & 138.05 & 61.80 & 268.40 \\
08.82 .004 & 227.09 & 956.15 & 89.76 & 1273.00 \\
09.81 .007 & 2011.45 & 49.16 & 22.21 & 2082.84 \\
17.94 .049 & 699.50 & 129.88 & 213.31 & 1042.70 \\
91.63 .001 & 231.27 & 180.66 & 443.54 & 855.48 \\
$\ldots \ldots$ & $\ldots \ldots$. & $\ldots \ldots$ & $\ldots$. & $\ldots$. \\
97.73 .002 & 129.14 & 593.96 & 36.11 & 759.222 \\
\hline
\end{tabular}

Fungsi Objective $=$

$$
\begin{aligned}
& P_{t}=\sum_{t=1}^{n} \sum_{k=1}^{c}\left(\left[\sum_{j=1}^{m}\left(X_{i j}-V_{k j}\right)^{2}\right]\left(\mu_{i k}\right)^{w}\right) \\
= & 268.40+1273+2081.84+1042.70+\ldots+855.48 \\
= & 85089.07
\end{aligned}
$$

Selanjutnya cek kondisi berhenti, dengan melakukan : a. Jika: (|Pt $-P t-1 \mid$ MaxIter $)$ maka berhenti b.Jika tidak: $t=t+1$. Hasilnya dapat dilihat pada tebel 15.

Tabel 15. Nilai LT

\begin{tabular}{lllll}
\hline NIK & C1 & C2 & C3 & Total \\
\hline 06.77 .003 & 0.0013 & 0.0006 & 0.025 & 0.0045 \\
08.82 .004 & 0.0003 & 0.0002 & 0.0004 & 0.0110 \\
09.81 .007 & 0.0003 & 0.0002 & 0.0004 & 0.0009 \\
17.94 .049 & 0.0003 & 0.0003 & 0.0004 & 0.0010 \\
91.63 .001 & 0.0003 & 0.0004 & 0.0003 & 0.0012 \\
$\ldots \ldots$ & $\ldots \ldots$ & $\ldots \ldots$ & $\ldots$. & $\ldots$. \\
97.73 .002 & 0.0006 & 0.0004 & 0.0001 & 0.0022 \\
\hline
\end{tabular}

Selanjutnya adalah menentukan keanggotaan baru dimana setiap klaster pada data LT dibagi dengan Total LT, sehingga didapatkan hasil berikut :

Tabel 16. Keanggotaan Baru

\begin{tabular}{llll}
\hline NIK & C1 & C2 & C3 \\
\hline 06.77 .003 & 0.288 & 0.143 & 0.568 \\
08.82 .004 & 0.359 & 0.236 & 0.403 \\
09.81 .007 & 0.327 & 0.209 & 0.463 \\
17.94 .049 & 0.328 & 0.283 & 0.388 \\
91.63 .001 & 0.311 & 0.399 & 0.289 \\
$\ldots \ldots$ & $\ldots \ldots$ & $\ldots \ldots$ & $\ldots$. \\
97.73 .002 & 0.313 & 0.189 & 0.497 \\
\hline
\end{tabular}

Selanjutnya menghitung selisih Objective pada iterasi pertama, dengan menggunakan nilai mutlak:

Selisih Objective $=$ ABS $($ Fungsi Objective -0$)$

$$
=\text { ABS (85089.07-0) }
$$$$
=85089.07
$$

Proses Iterasi ke 1 pada Fuzzy C-Means telah selesai, selanjutnya melanjutnya proses Iterasi Ke 2 dengan menggunakan keanggotaan baru pada tabel 16 (sebelumnya keanggotaan ditentukan secara random) dan dilakukan seterusnya hingga selisih fungsi objective kurang dari kesalahan terkecil. Perhitungan fungsi objective pada Iterasi Kedua,menggunakan rumus :

Selisih Objective $=\mathrm{ABS}($ Fungsi Objective Iterasi ke 2 - selisih objective Iterasi ke 1).

Untuk proses clustering menggunakan Fuzzy C-Means didapatkan pada iterasi ke 23, berikut adalah penjelasannya :

Selisih Fungsi Objective $=$ ABS(Fungsi Objective ke 23 - Selisih Fungsi Objective ke 22)

$$
\begin{aligned}
= & \operatorname{ABS}(30059.512716802 \\
& 30059.512717362) \\
= & 0.00000056
\end{aligned}
$$


Selisih fungsi objective pada Iterasi ke 23 < Kesalahan presensi karyawan menggunakan metode K-Means dan terkecil yang diharapkan.

Tabel 17. Tabel Hasil Clustering Fuzzy C-Means

\begin{tabular}{llllll}
\hline No & NIK & K1 & K2 & K3 & Hasil \\
\hline 1 & 06.77 .003 & 0.155 & 0.005 & 0.879 & C3 \\
2 & 08.82 .004 & 0.464 & 0.032 & 0.503 & C3 \\
3 & 09.81 .007 & 0.047 & 0.004 & 0.984 & C3 \\
4 & 17.94 .049 & 0.248 & 0.019 & 0.731 & C3 \\
5 & 91.63 .001 & 0.564 & 0.038 & 0.3997 & C1 \\
$\ldots$ & $\ldots \ldots$ & $\ldots \ldots$ & $\ldots$ & $\ldots$ & $\ldots$ \\
34 & 97.73 .002 & 0.044 & 0.002 & 0.953 & C3 \\
\hline
\end{tabular}

\subsection{Validitas}

\subsubsection{Validasi Algoritma K-Means}

Untuk mendapatkan validitas dari algoritma K-means, lainnya, maka semakin terlihat algoritma mana yang maka digunakan validitas Silhoutte Index. Hasil memang paling cocok untuk digunakan di studi kasus didapatkan dengan nilai Indeks rata-rata yang didapat clustering kinerja karyawan. adalah 0,528 .

\subsubsection{Validasi Algoritma Fuzzy C-Means}

Untuk mendapatkan validitas dari algoritma Fuzzy CMeans, maka digunakan validitas menggunakan Partition Coefficient Index (PCI) dengan rumus sebagai berikut:

a. Validasi PCI (Ui^2)

Tabel 18. Nilai validasi metode Fuzzy C-Means

\begin{tabular}{|c|c|c|c|c|}
\hline No & NIK & $\mathrm{K} 1$ & $\mathrm{~K} 2$ & K3 \\
\hline 1 & 06.77 .003 & 0,0134 & 2,6190 & 0,7727 \\
\hline 2 & 08.82 .004 & 0,2153 & 0,0010 & 0,2537 \\
\hline 3 & 09.81 .007 & 0,0022 & 1,7231 & 0,8993 \\
\hline 4 & 17.94.049 & 0,0004 & 0,9530 & 0,0001 \\
\hline 5 & 91.63 .001 & 0,3187 & 0,0014 & 0,1577 \\
\hline$\ldots$ & $\ldots \ldots$ & $\ldots$. & $\ldots$ & $\ldots$ \\
\hline 34 & 97.73 .002 & 0,0019 & 6,8709 & 0,9082 \\
\hline \multicolumn{4}{|c|}{ Jumlah Semua Kluster } & 25,784 \\
\hline
\end{tabular}

b. Nilai derajat keanggotaan

Tabel 19. Nilai derajat keanggotaan Algoritma Fuzzy C-Means

\begin{tabular}{lllll}
\hline No & NIK & K1 & K2 & K3 \\
\hline 1 & 06.77 .003 & 0,1159 & 0.0051 & 0.8790 \\
2 & 08.82 .004 & 0.4640 & 0.0322 & 0.5037 \\
3 & 09.81 .007 & 0.0475 & 0.0041 & 0.9483 \\
4 & 17.94 .049 & 0.0218 & 0.9669 & 0.0111 \\
5 & 91.63 .001 & 0.5646 & 0.0381 & 0.3971 \\
$\ldots$. & $\ldots \ldots$ & $\ldots \ldots$ & $\ldots$. & $\ldots$ \\
34 & 97.73 .002 & 0.0443 & 0.0026 & 0.9530 \\
\hline
\end{tabular}

$\mathrm{PCI}=(1 / 34)(25,784)=0,758$

\section{Kesimpulan}

\subsection{Simpulan}

Berdasarkan hasil penelitian yang telah diperoleh, dapat disimpulkan bahwa hasil cluster dari data Fuzzy C-Means berbeda. Hal ini dapat dilihat dari jumlah cluster yang diperoleh dari kedua metode tersebut. Dilihat dari hasil validasi, Fuzzy C-Means dominan menghasilkan metode yang lebih baik, dengan nilai validasinya adalah 0,758 dikarenakan nilai validasinya lebih mendekati nilai 1, dibandingkan dengan metode K-Means dengan nilai validasinya adalah 0,528 .

\subsection{Saran}

Penelitian ini masih dapat dikembangkan dengan membandingkan beberapa algoritma clustering lainnya, sehingga semakin banyak membandingkan algoritma

\section{Daftar Rujukan}

[1] H.T. Kahraman et al. The development of intuitive knowledge classifier and the modeling of domain dependent data. Knowledge-Based Systems 37 (2013) 283-295

[2] Agusta, Yudhi. K-Means - Penerapan, Permasalahan dan Metode Terkait. Jurnal Sistem dan Informatika. 2007; Vol. 3, 47-60.

[3] Simbolon, Cary Lineker. Clustering Lulusan Mahasiswa Matematika Fmipa Untan Pontianak Menggunakan Algoritma Fuzzy C-Means. Buletin Ilmiah Mat. Stat. Dan Terapannya (Bimaster). 2013; Volume 02, No.1, 21-26.Referensi yang berasal dari situs web

[4] Muzakir, Ari. Analisa Dan Pemanfaatan Algoritma K-Means Clustering pada Data Nilai Siswa Sebagi Penentuan Penerima Beasiswa. Prosiding Seminar Nasional Aplikasi Sains \& Teknologi (SNAST) 2014; Pp 195-200.

[5] Selviana, Nur Indah dan Mustakim. Analisis Perbandingan KMeans dan Fuzzy C-Means Untuk Pemetaan Motivasi Balajar Mahasiswa. Seminar Nasional Teknologi Informasi, Komunikasi dan Industri (SNTIKI) 8. 2016. Seminar Nasional Teknologi Informasi, Komunikasi dan Industri (SNTIKI) 9 ISSN (Printed) : 2579-7271 Fakultas Sains dan Teknologi, UIN Sultan Syarif Kasim Riau ISSN (Online) : 2579-5406 Pekanbaru, 18-19 Mei 2017226

[6] Mustakim. Pemetaan Digital dan Pengelompokan Lahan Hijau di Wilayah Provinsi Riau Berdasarkan Knoledge Discovery in Databases (KDD) dengan Teknik K-Means Mining. Seminar Nasional Teknologi Informasi, Komunikasi dan Industri (SNTIKI). 2012.

[7] J. O. Ong, "Implementasi Algoritma K-Means Clustering Untuk Menentukan Strategi Marketing President University," Ilmiah Teknik Industri, vol. 12, 2013.

[8] Jiawei, Han, dkk Data mining Concepts and Techniques. USA: Elsevier Inc. All rights reserved. 2012.

[9] Han, J dan Kamber, M., "Data Mining Concept and Technique", Morgan Kaufmann, 2001.

[10] Ghosh, S., Dubey, S.K., 2013. Comparative Analysis of $K$ Means and Fuzzy C-Means Algorithms. International Journal of Advanced Computer Science and Applications, Vol. 4, No.4 